\title{
ECONGTOR
}

\section{A Service of}

Make Your Publications Visible.

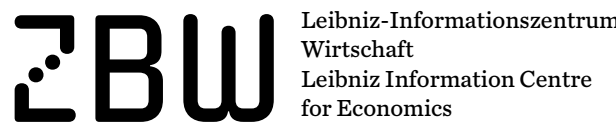

Guilhoto, Joaquim; Costa, Cinthia; Cunha, Marcelo; Araujo, Kathleen

\section{Conference Paper \\ The Role of Ethanol in the Brazilian Economy: Three Decades of Progress}

51st Congress of the European Regional Science Association: "New Challenges for European Regions and Urban Areas in a Globalised World", 30 August - 3 September 2011, Barcelona, Spain

Provided in Cooperation with:

European Regional Science Association (ERSA)

Suggested Citation: Guilhoto, Joaquim; Costa, Cinthia; Cunha, Marcelo; Araujo, Kathleen (2011) : The Role of Ethanol in the Brazilian Economy: Three Decades of Progress, 51st Congress of the European Regional Science Association: "New Challenges for European Regions and Urban Areas in a Globalised World", 30 August - 3 September 2011, Barcelona, Spain, European Regional Science Association (ERSA), Louvain-la-Neuve

This Version is available at:

http://hdl.handle.net/10419/120270

Standard-Nutzungsbedingungen:

Die Dokumente auf EconStor dürfen zu eigenen wissenschaftlichen Zwecken und zum Privatgebrauch gespeichert und kopiert werden.

Sie dürfen die Dokumente nicht für öffentliche oder kommerzielle Zwecke vervielfältigen, öffentlich ausstellen, öffentlich zugänglich machen, vertreiben oder anderweitig nutzen.

Sofern die Verfasser die Dokumente unter Open-Content-Lizenzen (insbesondere CC-Lizenzen) zur Verfügung gestellt haben sollten, gelten abweichend von diesen Nutzungsbedingungen die in der dort genannten Lizenz gewährten Nutzungsrechte.
Terms of use:

Documents in EconStor may be saved and copied for your personal and scholarly purposes.

You are not to copy documents for public or commercial purposes, to exhibit the documents publicly, to make them publicly available on the internet, or to distribute or otherwise use the documents in public.

If the documents have been made available under an Open Content Licence (especially Creative Commons Licences), you may exercise further usage rights as specified in the indicated licence. 


\title{
The Role of Ethanol in the Brazilian Economy: Three Decades of Progress
}

\author{
Cinthia Cabral da Costa \\ Researcher of Embrapa Instrumentation Station \\ E-mail: cinthia.cabral.da.costa@gmail.com \\ Marcelo Pereira da Cunha \\ Brazilian Bioethanol Science and Technology Laboratory, CTBE \\ E-mail: marcelo.cunha@bioetanol.org.br \\ Joaquim José Martins Guilhoto \\ Department of Economics, FEA - University of São Paulo \\ REAL, University of Illinois, and CNPq Scholar \\ E-mail: guilhoto@usp.br

\section{Paper Presented at the \\ $51^{\text {st }}$ Congress of the European Regional Science Association \\ Barcelona, Spain - August 30 ${ }^{\text {th }}$ to September $3^{\text {rd }}, 2011$}

\begin{abstract}
Sustainable energy strategies require decision-makers in government, industry, academia and civil society alike to make choices among tradeoffs. Within the transport sector alone, ethanol has been shown to be the dominant solution among viable, low carbon options to date, yet questions remain over the economic and ecological impacts of this industry.

In Brazil - the largest producer of sugarcane-based ethanol and a country with over three decades of ethanol development - we find a strong basis for evaluating the ethanol industry's role in a national economy. In the mid 1970's, Brazilian ethanol production received an important boost with the launch of the "Proálcool" program. The ethanol industry has subsequently evidenced flux until its consolidation in the period following 2000.

Over the course of three decades, economic, institutional, technological and environmental determinants have factored in the success of Brazilian ethanol diffusion. In economic terms, price tradeoffs for ethanol vs. sugar and ethanol vs. gasoline played a role in scale-up of the biofuel together with balance of payment considerations. From an institutional standpoint, support for the Proálcool program, deregulation of the sugar-cane sector in the 1990 's and fuel pump adaptations also factored. With respect to technology, the development of flex fuel cars, greater use of mechanized harvesting, and launch of domestic, co-generated, electrical power were key drivers. Finally, in environmental terms, challenges associated with pollution and public health in major cities as well as questions related to climate change gained visibility.

In this paper, we analyze a set of input-output tables for the Brazilian economy from 1975 to 2006, taking the above factors into consideration. Deriving a series of indicators, such as multipliers and linkages, we study the evolution of the ethanol sector's role in the Brazilian economy and its relation to the productive structure of the country.
\end{abstract}

Key words: Brazil, Ethanol, Input-Output, Productive Structure. 


\section{Introduction}

Sustainable energy strategies require decision-makers in government, industry, academia and civil society alike to make choices among tradeoffs. Within the transport sector in Brazil, ethanol has been shown to be the dominant solution among viable, low carbon options. As a consequence of increased demand, between 1970 and 2008/09, ethanol production has grown 10 percent per annum on average, boosting sugarcane production by 6 percent per annum on average.

The Brazilian system of production and consumption of ethanol has characteristics that distinguish it from that in other countries. On the side of production, the role of ethanol in the economy is influenced by the production of sugar, with dual role: a) on one hand sugar and ethanol can be seen as a competitors for the demand of the raw material sugarcane (which in turn is different and more competitive than the raw materials used in others countries); but b) on the other hand it should be noted that part of the success of Brazilian ethanol is precisely due to the fact that its production can be made with sugar, i.e. sugar production allowed for a long period, the ethanol being produced as a by-product of sugar, allowing it to become more competitive, in this sense, the products of ethanol and sugar cane sugar should be viewed from the perspective of economy of scope, and not as a competition of one against the other. For this reason, an understanding of the structure of the sugar sector should be important to assessing the ethanol sector in the Brazilian economy. On the demand side, ethanol is used as a substitute for and complement to gasoline: a) as a substitute, because in Brazil, now a days, around $40 \%$ of vehicles are flex-fuel cars that can run on any combination of ethanol and gasoline; and b) as a complement, since at the pump, gasoline in this country has to be a mix of gasoline and ethanol, to around 20-25 percent ethanol (E20 or E25) ${ }^{1}$, which is called gasohol. In other countries, there is only the gasohol and the commonest mixtures are 5 and 10 percent ethanol in gasoline (E5 and E10).

Brazil is the second world's largest producers and consumers of ethanol. Together with the United States, Brazil accounted for 86 percent of the market in 2009 (LMC 2010). The ethanol industry in Brazil was incentivized in the 1970s and has suffered changes since then. Thus, the participation of ethanol in the Brazilian energy matrix has not been constant. This has many causes - economic, institutional, technological and environmental. For instance: a)

\footnotetext{
${ }^{1}$ In Brazil, ethanol is used as a blend with gasoline since the 1930s. The first blend was 5 percent of ethanol in gasoline (E5). In 1966 ethanol content grew to 25 percent (E25). In 1976, it fell to 11 percent (E11) and increased again in 1978 to E18-20-23 (Puerto Rico, 2007). By 2010, the blend ranged between 20 and 25 percent. In 2011, because of scarce supplies, the authorized blend changed to between 18 and 25 percent (E1825).
} 
while in the 1970s ethanol fuel was planned to be used in an adapted motor that replaced a gasoline one, in the 2000s ethanol has been used in flex-fuel vehicles; b) while until the 1990s sugarcane to produce ethanol was cut by hand, only after the outside leaves were burned, in the 2000s mechanized harvesting began to be used, because of a law prohibiting sugarcane burning by $2014^{2}$; c) while more than 80 percent of the sugarcane was used to produce sugar until 1978, the share of the sugarcane used in ethanol production was more than 60 percent in the 1980s and 1990s and has been about 50 percent in the 2000s (Brazil, 2009); d) while the total sugarcane harvest was 57 billion tons in 1970/71, it was almost seven times greater in 2005/06 (Brazil, 2009); e) while Brazil was a net importer of ethanol in the 1990s, after 2004 the country exported more than 2.5 million $\mathrm{m}^{3}$ of this fuel (Brazil, 2009); $\mathrm{f}$ ) in the sugar market, the exports increased from 1995 to 2008 at a growth rate of 11 percent per annum on average; and g) while the government regulated the sugarcane agroindustrial sector up to the 1990s, in the 2000s they do not, although some policies have been implemented in the last decade that impact the ethanol market.

All these features of the ethanol market molded the role of this product in the Brazilian economy over the course of three decades. Other changes are still in progress in this market: a) the domestic market will expand greatly because of the growing fleet of flex-fuel vehicles (according to the Unica ${ }^{3}$, half of the vehicles will be flex-fuel by 2012); b) mechanization of sugarcane cutting is yet to be completed; c) the milled sugarcane biomass has much to offer as a renewable energy source, mainly with the expanded use of the remains (bagasse and straw) of unburned cane; d) the development of second generation ethanol; e) the international market is beginning and there are trade barriers to be eliminated; and f) the Brazilian government can use policy decisions to increase or decrease support ethanol production and demand.

In this study, we analyzed the ethanol and related sectors on the production and demand side. A set of input-output tables for the Brazilian economy from 1975 to 2006 were analyzed, taking the above factors into consideration.

This paper is organized as follows, in the next section, we present the history of ethanol in Brazil; after that, the theoretical background of the multipliers and linkages is described, followed by a description of the database used in the paper; we then go to the analysis of the results obtained in this paper, in which the developing of the ethanol sector in the Brazilian

\footnotetext{
${ }^{2}$ According to Moraes (2007), unburned sugarcane is viable only with mechanized harvesting and, consequently, between 1992 and 2005, while the number of cane cutters decreased by 23 percent, production grew by 54.6 percent.

${ }^{3}$ Brazilian Sugarcane Industry Association.
} 
economy is analyzed in relation to the productive structure of the country; the final comments are made in the last section.

\section{Ethanol in Brazil}

The importance and success of the Brazilian ethanol program has its origin at the establishment of sugarcane in Brazil for sugar production. Sugarcane was brought to Brazil in 1533, and was responsible for a period of great importance in social and economic history of the country - known as "sugar cycle" -, phase between the middle of the sixteenth century to the end of the seventeenth by the establishment of sugar production in Brazilian Northeast in order to export sugar to the European countries. At that time, Brazil became the largest world producer and exporter of the commodity. Afterwards, sugar production in Brazil has gone through cycles of crisis and prosperity, but never ceased to be one of the main economic activities of the Brazilian agriculture.

The firsts Brazilian tests using sugarcane ethanol as fuel occurred in the early 1920's; after good results, Brazilian Government, by Decree 19.717 in 1931, authorizes the addition of up to $5 \%$ anhydrous ethanol to gasoline in order to reduce the impacts from the dependence of the gasoline imported, as well to use molasses coming from the mills producing sugar. The use of anhydrous ethanol blended to gasoline was kept from 1931, and remained around $7.5 \%$ on average until 1975 (BNDES, 2008; CGEE, 2009).

However, due to the first international oil crisis occurred in the first half of the 1970's, Brazil launched, on 15 November 1975, The Brazilian Ethanol Program - Proálcool dedicated exclusively to the production of sugarcane fuel ethanol. At that period the country was heavily dependent on oil imports. From 1973 to 1974, Brazilian oil imports rose from US\$ 600 million to US\$ 2.5 billion, contributing to the trade deficit of US\$ 4.7 billion in 1974 (BNDES, 2008; CGEE, 2009). The Proálcool, established by Decree 76.593, had as main objectives (i) reduce national dependence on oil imports, (ii) promote technological and industrial development associated with ethanol fuel production chain and (iii) strengthen the sugarcane and sugar sectors (CGEE, 2009).

In its first phase, Proálcool had as its goal the production of anhydrous ethanol to be blended into gasoline by $25 \%$ by volume, bringing great benefit to the reduction of pollutants emissions, replacing the use of tetraethyl lead (BNDES, 2008; CGEE, 2009). In its second phase, through centralized coordination of the Federal Government with the alcohol sector, auto industry and the research centers and universities, the focus was put towards the 
production of hydrated ethanol fuel for use in vehicles dedicated solely for this purpose; with this goal, the first car powered only by hydrated alcohol was manufactured in the country in 1979 , precisely during the $2^{\text {nd }}$ oil crisis, when oil reaches the apex of its price a few months later, in 1980, as illustrated in Figure 1.

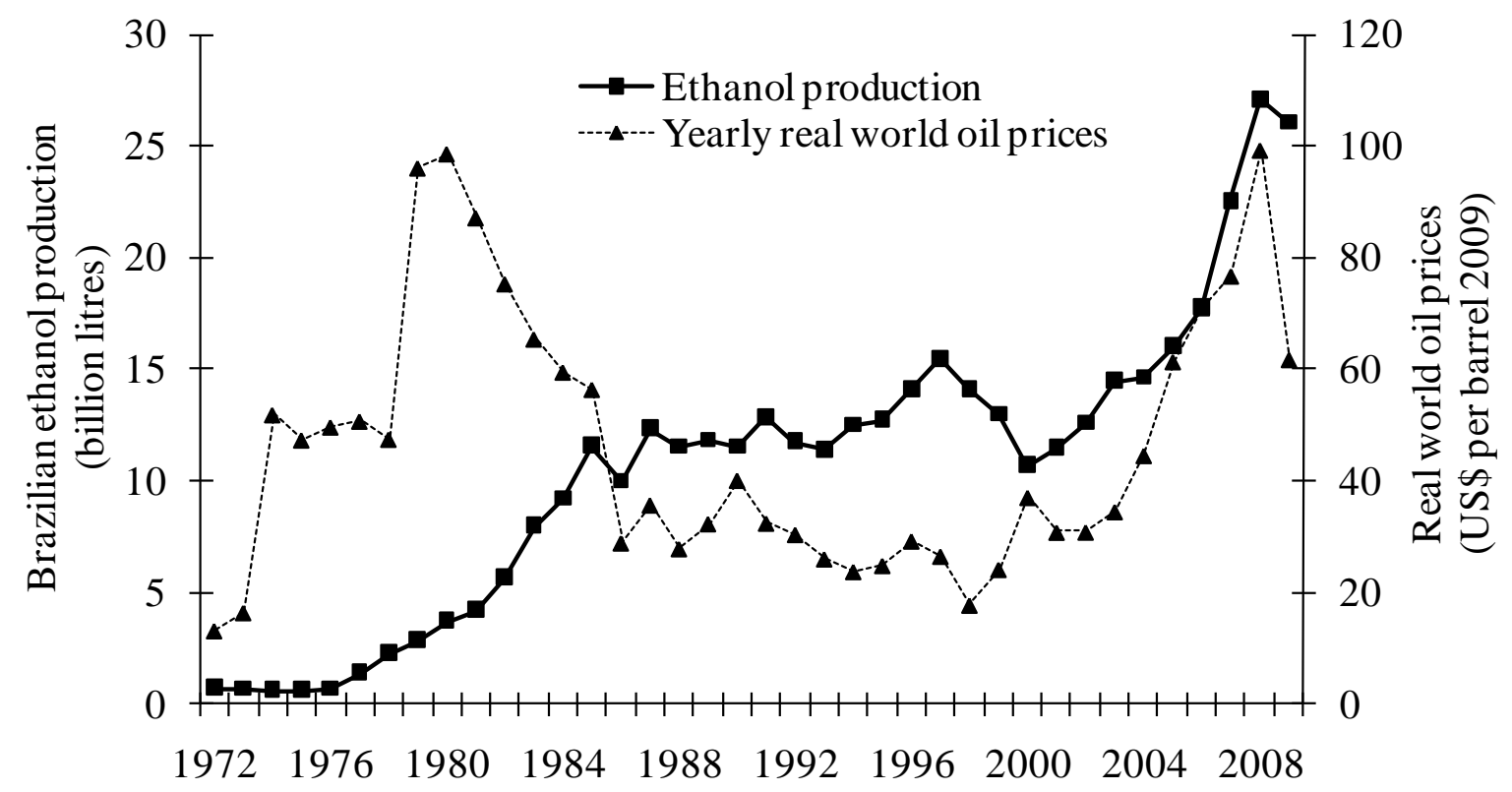

Figure 1 - Evolution of Brazilian ethanol production and real world oil prices

Source: Oil prices: BP (2009) and EIA (2010); Brazilian ethanol production: EPE (2010) and Brazil (2009)

During the first half of 1980's, when hydrated ethanol prices were subsidized by gasoline prices, production and commercialization of alcohol vehicles have expanded dramatically, so that the production of these vehicles reached $76 \%$ of the total in 1985 and 1986, as shown in Figure 2.

From the 2nd half of the 1980's to 1990's (Figure 1) there was a sharp drop in international oil prices, bringing great pressure on the subsidies needed to alcohol to make it price competitive with gasoline. In the late 1980's, coupled with the rise of sugar prices in international market, there was a supply crisis for hydrous ethanol in the domestic market, becoming necessary to import methanol from abroad, as an emergency action, to supply part of the domestic market. The maintenance of oil prices at a lower level, rising international sugar prices and the crisis caused in the late 1980's by the scarcity of hydrated ethanol in Brazil resulted in a drastic reduction in the production of ethanol vehicles in the country, becoming negligible since 1996, as shown in Figure 2. 


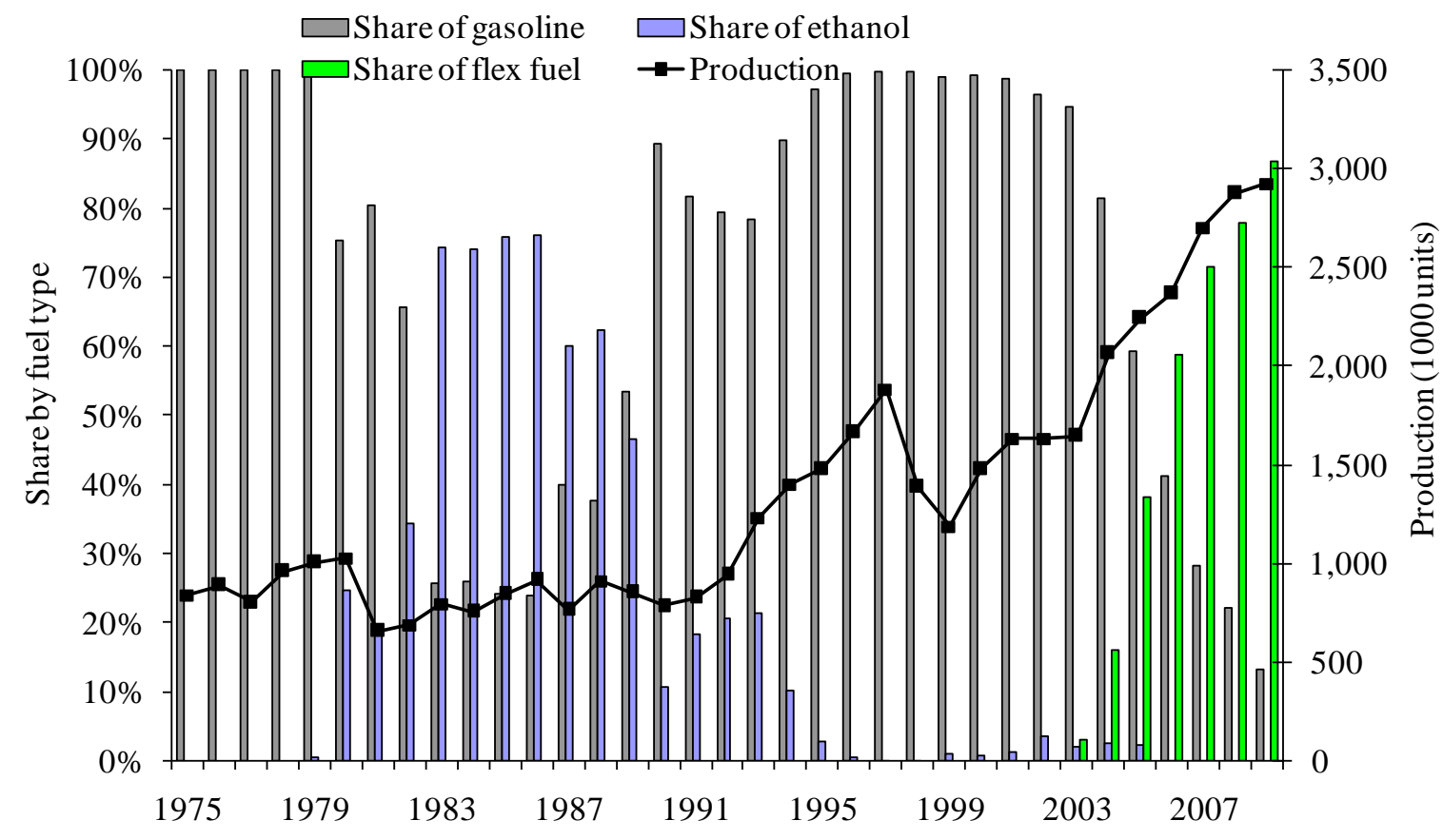

Figure 2 - Evolution of Brazilian light vehicles production and share by fuel type

Source: Brazilian Automotive Industry Association (2010).

After rights and wrongs over the 25 years since the Proálcool was launched, the fact is that there was a continuous improvement in the productivity of sugarcane in the country as well as increase the efficiency of the manufacturing related to ethanol production. From observed data (IBGE, 2010; Brazil, 2009), between 1975 and 2000, one notice that sugarcane productivity (ton/ha) raised 44.2\% (65.6\% between 1975 and 2008) and ethanol productivity (L/ha) raised $90.8 \%$ (124.9\% between 1975 and 2008). With the establishment of the Real Plan in 1994, the last more important economic reform in Brazil, the production of fuel ethanol had no more subsidies in 1999 (BNDES and CGEE, 2008); it is estimated that there was a savings of US\$ 50 billion due to oil imports avoided, considering the consumption of ethanol in the country between 1975 and 2002 (Goldemberg et al., 2004)

In the early 2000 's, prices for hydrous ethanol ranged from $50 \%$ to $60 \%$ of the price of gasoline at the pump, but the production of alcohol cars remained stagnant due to the reflections of the supply crisis of 1989. Realizing the opportunity due to the supply of cheap ethanol in Brazil, the auto industry launched, in 2003, the flex fuel vehicles, capable of using any blend of gasoline (with a content between $20 \%$ to $25 \%$ anhydrous ethanol) and hydrous ethanol, including $100 \%$ of any one of them. The new technology was an immediate success 
among the Brazilian consumers and in just over six years, new flex fuel cars reached over $87 \%$ of the sales of new cars in 2009 (Figure 2).

Naturally, the raise for fuel ethanol demand in the country have brought a recent cycle of ethanol production in Brazil, as noted in Figure 1. In particular, the sugar-alcohol sector has experienced, in the last decade, a period of great expansion, motivated by the circumstances of domestic demand for ethanol and international demand for sugar due to very favorable prices.

In terms of sustainability, the production of sugarcane ethanol is recognized as the best route in terms of reduction of greenhouse gases emissions and energy balance, reducing these emissions from $80 \%$ to $90 \%$ and obtaining 9 units of energy (contained in ethanol) from 1 unit of fossil energy (Macedo and Seabra, 2008). These exceptional conditions are achieved by the use of bagasse as an energy source for the industrial process, ensuring even the supply of surplus of electricity, which tend to be even greater with the advent of the harvest of green sugarcane without burning. In 2009, according to EPE (2010), sugarcane bagasse was responsible for $3.0 \%$ of all Brazilian electricity generation; it is estimated that with current production of sugarcane and using the best technology commercially available, these surpluses could add around 10\% of all Brazilian electricity generation (CGEE, 2009).

Finally, it is essential to highlight the opportunity that represents for the country the possibility of bioethanol becomes an international commodity. Brazil is the country that combines the best natural, technological and institutional conditions to expand its production of sugarcane bioethanol in a sustainable way to meet world demand without jeopardizing food production (CGEE, 2009). According to IBGE (2009), in 2009, the country used 65.6 Mha with agriculture (mainly uses are 21.8 Mha with soy, 14.1 Mha with corn, 4.5 Mha with sugarcane to produce ethanol and 4.3 Mha with sugarcane to produce sugar) and around 200 Mha with pasture - occupying a head per hectare on average. The Brazilian Sugarcane Agroecological Zoning identifies close to 65Mha suitable for the expansion of sugarcane (EMBRAPA, 2009); improving the pasture intensification from 1 head per hectare to 1.1 , would be available 20 Mha more, which could be employed to quintuple the current ethanol production in Brazil - a volume close to 150 billion liters per year, capable to replace roughly $10 \%$ of world gasoline consumption. 


\section{Theoretical Background}

The structural changes that have occurred in the ethanol sector since the 1970s and its insertion in the Brazilian economy have been assessed by input-output matrix analysis. This approach can identify the relationship among the various sectors, revealing the importance of each within the economy. Here, we explain the theoretical basis of the analysis. Initially, we describe the production multipliers and, after that, the linkage indices and the pure linkage indices.

\subsection{Multipliers}

According to Miller \& Blair (2009), we can calculate the output of an economy as:

$$
A X+Y=X
$$

Where $X$ and $Y$ are respectively the output and the final demand vectors, respectively, and $A$ is a matrix of technical coefficients for production.

From equation (1) it follows that demand shocks impact the output value of the economy. This is estimated as follows:

$$
X=B Y
$$

where $B=(I-A)^{-1}$, which takes direct and indirect impact into account and is described as the Leontief inverse matrix.

From this Leontief inverse matrix, we obtain the output multipliers type I. These multipliers are the direct and indirect effects of the shocks. We can also find the income impact corresponding to the increase in the household demand resulting from direct and indirect impact of the increase in the economic activity, type II multipliers. This last impact is obtained by closing the model in relation to the households. In this case, the inverse Leontief matrix is obtained from a matrix $\bar{A}$ of technical coefficients, where the household consumption is treated as endogenous, so that the sector multiplier is calculated from the $\operatorname{matrix}(I-\bar{A})^{-1}$.

Thus, the total output of the economy that is driven to meet the change in final demand is obtained as follows:

$$
\begin{aligned}
& \bar{X}=(I-\bar{A})^{-1} \bar{Y} \\
& \bar{X}=\bar{B} \bar{Y}
\end{aligned}
$$

where $\bar{B}=(I-\bar{A})^{-1}$. 
Based on the Leontief system other indicators, like the Hirschman-Rasmussen and the Pure interindustry linkages presented bellow can be estimated and used to better understand the economic relations and the productive structure of a given economy.

\subsection{Interindutsry Linkages}

There is a lengthy literature devoted to the concept of key sector analysis, Rasmussen and Hirschman's notions have received widespread application and significant critical commentary (see, for example, McGilvray, 1977, Hewings, 1982). These debates will not be revisited in this paper; rather, the focus will begin with a brief presentation of the Rasmussen and Hirschman approach followed by a more detailed presentation of the work proposed by Guilhoto, Sonis e Hewings (2005).

The work of Rasmussen (1956) and Hirschman (1958) led to the development of indices of linkage that have now become part of the generally accepted procedures for identifying key sectors in the economy.

Define $b_{i j}$ as a typical element of the Leontief inverse matrix, $B ; B^{*}$ as the average value of all elements of $B$, and $B_{*_{j}}$ the associated typical column sum, then the backward indices may be developed as follows:

$$
U_{j}=\left[B_{*_{j}} / n\right] / B^{*}
$$

Defining $F$ as being the matrix of the row coefficients obtained from the intermediate consumption matrix; $G$ as the Ghosh matrix obtained from $G=(I-F)^{-1}$ (see Miller e Blair, 2009); $G^{*}$ as the average value of all elements of $G$, and $G_{i^{*}}$ the associated typical row sum, then the forward indices may be developed as follows:

$$
U_{i}=\left[G_{i^{*}} / n\right] / G^{*}
$$

According to Rasmussen (1956) and Hirschman (1958), the sectors with indices higher than one are the main sectors in the economy: sectors with a backward linkage index higher than one are input consumers and those with a forward linkage index higher than one are input suppliers. Miller \& Blair (2009) distribute the sectors in four classes: (1) generally independent of (not strongly connected to) other sectors; (2) dependent on interindustry demand; (3) dependent on interindustry supply and (4) generally dependent on (connected to) other sectors. Table 1 relates these classes to backward and forward linkage indices. 
One of the criticisms of the above indices is that they do not take into consideration the different levels of production in each sector of the economy, which is done by the Pure linkages as developed and presented by Guilhoto et al. (1994) and by Guilhoto, Sonis and Hewings (2005), and summarized below.

Table 1 - Classification of Backward and Forward Linkage Results

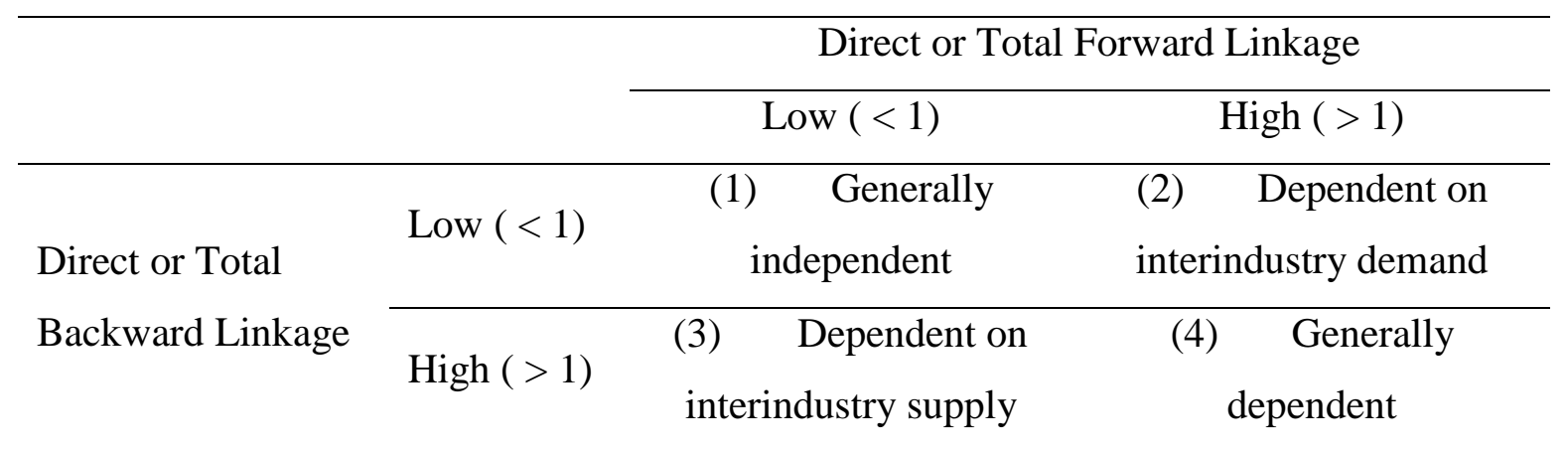

Source: Miller \& Blair (2009).

Consider a technical coefficients matrix represented by the following block A matrix:

$$
\boldsymbol{A}=\left[\begin{array}{ll}
\boldsymbol{A}_{j j} & \boldsymbol{A}_{j r} \\
\boldsymbol{A}_{r j} & \boldsymbol{A}_{r r}
\end{array}\right]=\left[\begin{array}{cc}
\boldsymbol{A}_{j j} & \boldsymbol{A}_{j r} \\
\boldsymbol{A}_{r j} & \mathbf{0}
\end{array}\right]+\left[\begin{array}{cc}
\mathbf{0} & \mathbf{0} \\
\mathbf{0} & \boldsymbol{A}_{r r}
\end{array}\right]=\boldsymbol{A}_{j}+\boldsymbol{A}_{r}
$$

where $\boldsymbol{A}_{j j}$ is the matrix of direct inputs to sector $j$ from itself; $\boldsymbol{A}_{\boldsymbol{r} j}$ is the matrix of direct inputs that sector $j$ acquires from the rest of the economy; $\boldsymbol{A}_{j r}$ is the matrix of direct inputs that the rest of the economy acquires from sector $j ; \boldsymbol{A}_{r r}$ is the matrix of direct inputs that the rest of the economy acquires from itself; $\boldsymbol{A}_{\boldsymbol{j}}$ refers to the sector $j$ isolated from the rest of the economy; and $\boldsymbol{A}_{\boldsymbol{r}}$ represents the rest of the economy.

From (7), one can generate the following expression:

$$
\boldsymbol{B}=(\mathbf{I}-\boldsymbol{A})^{-1}=\left(\begin{array}{ll}
\boldsymbol{B}_{j j} & \boldsymbol{B}_{j r} \\
\boldsymbol{B}_{r j} & \boldsymbol{B}_{r r}
\end{array}\right)=\left(\begin{array}{cc}
\boldsymbol{\Delta}_{i j} & \mathbf{0} \\
\mathbf{0} & \Delta_{r r}
\end{array}\right)\left(\begin{array}{cc}
\Delta_{j} & \mathbf{0} \\
\mathbf{0} & \Delta_{r}
\end{array}\right)\left(\begin{array}{cc}
\boldsymbol{I} & A_{j r} \Delta_{r} \\
A_{r j} \Delta_{j} & \boldsymbol{I}
\end{array}\right)
$$

where:

$$
\begin{aligned}
& \Delta_{j}=\left(I-A_{j j}\right)^{-1} \\
& \Delta_{r}=\left(I-A_{r r}\right)^{-1} \\
& \Delta_{j j}=\left(I-\Delta_{j} A_{j r} \Delta_{r} A_{r j}\right)^{-1} \\
& \Delta_{r r}=\left(I-\Delta_{j} A_{r j} \Delta_{j} A_{j r}\right)^{-1}
\end{aligned}
$$


From equation (8) it is possible to reveal the process of production in an economy as well as derive the Pure Backward Linkage $(P B L)$ and the Pure Forward Linkage $(P F L)$, i.e.,

$$
\begin{aligned}
& P B L=\Delta_{r} A_{r j} \Delta_{j} Y_{j} \\
& P F L=\Delta_{j} A_{j r} \Delta_{r} Y_{r}
\end{aligned}
$$

where the $P B L$ will give the pure impact on the rest of the economy of the value of the total production in region, i.e., the impact that is free from a) the demand inputs that region $j$ makes from region $j$, and $\mathrm{b}$ ) the feedbacks from the rest of the economy to region $j$ and vice-versa. The PFL will give the pure impact on region $j$ of the total production in the rest of the economy

Other advantage of the Pure linkages in relation to the Hirschman-Rasmussen linkages is that it is possible to get the Pure Total linkage in the economy ( $P T L)$ by adding the $P B L$ and the $P F L$, given that this index are measured in current values, i.e.,

$$
P T L=P B L+P F L
$$

To facilitate a comparative analysis of the pure linkages with the HirschmanRasmussen linkages one can do a normalization of the pure linkages. This normalization is done by dividing the pure linkage in each sector by the average value of the pure linkage for the whole economy, in such a way that the pure linkages normalized are given by the following equations for the backward (PBLN), forward (PFLN) and total (PTLN) linkages:

$$
\begin{aligned}
& P B L N_{i}=P B L_{i} /\left(\sum_{i=1}^{n} P B L_{i} / n\right) \\
& P F L N_{i}=P F L_{i} /\left(\sum_{i=1}^{n} P F L_{i} / n\right) \\
& P T L N_{i}=P T L_{i} /\left(\sum_{i=1}^{n} P T L_{i} / n\right)
\end{aligned}
$$

\section{The Database}

For the purposes of this analysis, the input-output data for Brazil refer to the years of $1970 ; 1975 ; 1980 ; 1985 ; 1992 ; 1995 ; 1997 ; 1999 ; 2002 ; 2004$ and 2006. The Instituto Brasileiro de Geografia e Estatística (IBGE) is responsible for organizing and issuing the input-output matrix, but it is not available for all years. The most recent document made 
available is 2005 (IBGE, 2011). However, as described by Guilhoto and Sesso Filho (2005 and 2010), this matrix can be estimated from some tables in the National Accounts, which are available for all years, with a delay of two or three years. Therefore, some matrices used in this study were estimated according to the above methodology.

The sectors chosen for analysis were the main sectors involved in changes in the Brazilian fuel structure industry described above. Fossil fuel is the other player in the fuel market and the ethanol industry uses sugarcane as input, sugar itself being the substitute product in Brazil. Therefore, the sectors focused on in this study were: sugarcane, ethanol, sugar, oil extraction and petroleum refining. In general terms, the input-output matrix divulged by the IBGE did not distinguish all these sectors in all the years analyzed. Besides, other sectors detailed in the matrix are not important for this study. Consequently, the input-output matrix used in this analysis to represent the Brazilian economy represents some sectors in a more disaggregated form than in the IBGE matrix, while others are lumped into in a more aggregated form. The last document divulged by IBGE described a Brazilian economy with 56 sectors and this study used a matrix composed by 26 sectors. This aggregation was important to have all matrices compatible among themselves.

\section{Results and Discussion}

The objective of this study was to identify the changes in the interrelations between the ethanol sector and the Brazilian economy in the last three decades. For this reason, some indices and impacts that shed light on this relationship have been presented. The analysis included not only the ethanol sector, but also some other related sectors: sugar, sugarcane, oil extraction and petroleum refining. First, we measured the impact upon the value of ethanol production in the Brazilian economy of demand shocks in the sectors analyzed in each period. Secondly, the connection between each sector analyzed and the rest of the economy was measured in terms of backward and forward linkage indices.

\subsection{Production Multipliers of Type I and of Type II}

The estimates obtained for the multipliers of type I and of type II for each of the main sectors and periods analyzed are presented in Figure 3 and 4, respectively. Type I multipliers are derived from matrix B (equation 2), while type II take household consumption into account, being obtained from $\bar{B}$ (equation 3 ). 
The production multipliers of type I illustrated in Figure 3 shows that an increase in final demand in the ethanol and sugar sectors promoted a twofold increase in the production value in these sectors, in most of the period analyzed. This did not occur either in the other sectors analyzed or in the whole Brazilian economy. However, this impact of final demand appears to be falling over time. While an increase in demand of one million (Brazilian Reais, $\mathrm{R} \$$ ) for ethanol in 1975 increased Brazilian production by 2.2 millions, in 2006 this same shock impacted the production by 1.8 million. In the sugar sector, while an increase of one million in its demand in 1975 boosted Brazilian production by 2.5 millions, in 2006 the same one million demand shock raises total production by 2.1 millions. In the other sectors analyzed here, the opposite trend is seen; that is, for the same one million increases in demand, the impact on total production increased over time. For the sugarcane sector for example, while the increase in production was 1.5 million in 1975, it was 1.6 million in 2006; in oil extraction, the multipliers was 1.1 in 1970 and 1.7 in 2006; in petroleum refining, it was 1.4 in 1970 and 2.4 in 2004.

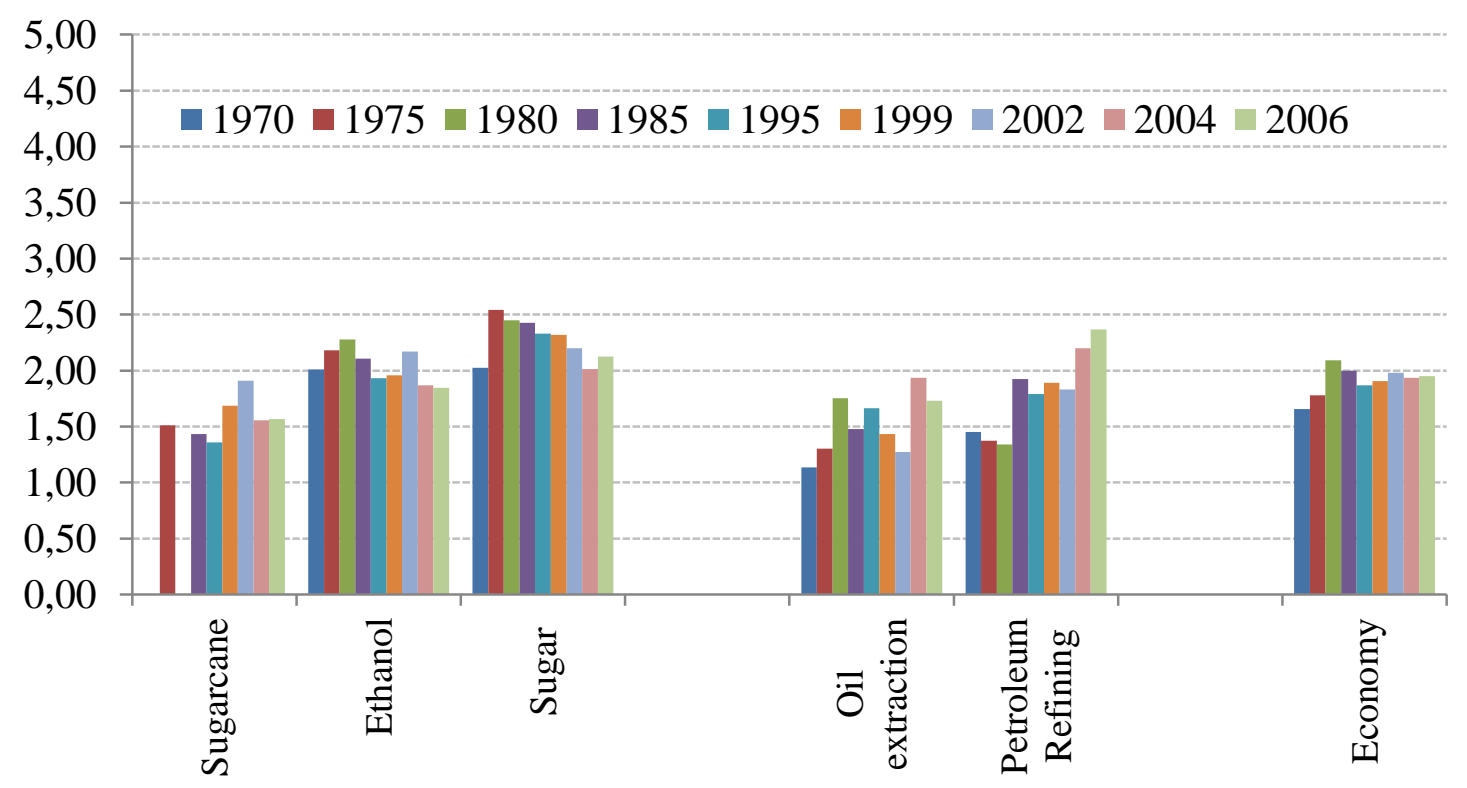

Figure 3 - Production multipliers of type I for select sectors of the Brazilian economy, 1970 to 2006.

Source: research results 


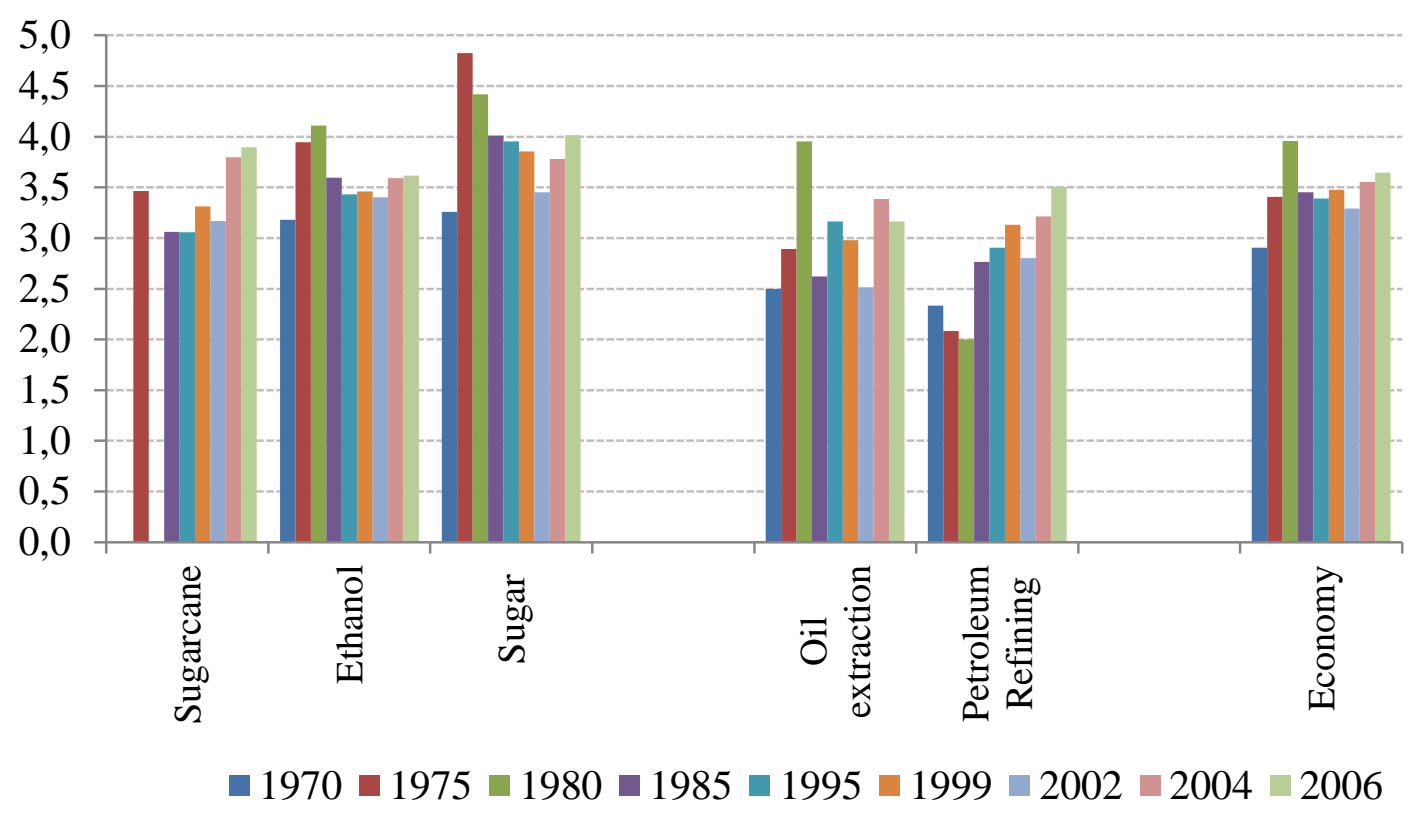

Figure 4 - Production multipliers of type II for selected sectors of the Brazilian economy, 1970 to 2006.

Sources: research results

The reduction in impact of the sugar and ethanol sector could be associated with an increase in the efficiency of these sectors caused by deregulation in the 2000s, leading to higher production of these products. On one hand, an increase in efficiency means that the industry uses less input and reduces the effect of the multipliers on the economy. On the other hand, this promotes an incentive to increase the supply which boosts the impact on the economy.

The results shown in Figure 4 (production multipliers of type II) are almost double those described in Figure 3. This is because the income effect is estimated, by the incorporation of household consumption as a sector in the input-output matrix. The effect of income was proportionally larger in the sugarcane sector than in others. While the impact on total production was 2.2 times greater than the shock in demand in this sector, in other sectors the impact in total production was less than 2 times. For all sectors analyzed, type II production multipliers raise over time, including the ethanol and sugar sectors. However, in oil extraction and petroleum refining sectors, this effect was more marked. While in 1970 an increase in demand of one million for oil extraction and petroleum refining boost Brazilian production by 2.5 and 2.3 million, respectively, in 2006 these same shocks improve Brazilian production by 3.2 and 3.5 million, respectively.

Comparing the sugar agro-industry sectors and the petroleum sectors, it is clear that the first have more impact on the economy than the second (Figures 3 and 4). Besides, 
considering the investment needed to generate fuel, we conclude that sugarcane produces much more benefits for the Brazilian economy than petroleum refining. When the employment created is included in our analysis, this conclusion gains power. According to Goldember et al. (2008), while petroleum generates one job per unit of energy, ethanol generates 152. Moreover, these same authors reported that the petroleum sector needs US\$220 thousand to create one job, against US\$11 thousand in the ethanol sector.

Data from the 2006 input-output matrix show that the employment coefficient was 0.55 for oil extraction and 0.15 for petroleum refining. The cane agro-industry shows, for the same year, an employment coefficient of 4.3 for ethanol; 8.0 for sugar and 37 for sugarcane. Assuming totally mechanized harvesting, this last coefficient falls to above 10. Therefore, corroborating Goldember et al. (2008), we found the economic and social importance of ethanol as fuel to be greater than that of petroleum products.

\subsection{Backward and Forward Linkages}

The results shown above do not consider the relative importance of the sectors analyzed to the other sectors in the Brazilian economy. To evaluate this question, backward and forward linkages are presented and analyzed in this section.

\subsubsection{The Rasmussen-Hirschman Linkages}

Figures 5 and 6 present the results for the forward (FL) and backward (BL) RasmussenHirschman linkages, respectively, for the sectors and years analyzed in this study. As expected, the FL is greater for sugarcane than ethanol and sugar because the sugarcane supplies material to these other sectors. Since the FL for sugar was less than one for all years analyzed, this sector is classified as independent of the interindustry demand. All the other sectors are key input suppliers in the Brazilian economy because their FLs are higher than one. Although oil extraction supplies petroleum refining, both of them have higher forward linkages. This is because the petroleum refining sector supplies many other sectors in the economy. In descending order of importance as suppliers, the sectors can be ranked as follows: oil extraction; sugarcane; petroleum refining and ethanol. Regarding ethanol, it is interesting to observe that its FL decreased from 2002 to 2006. This can be explained because, before 2004, much ethanol was input to petroleum refining to produce gasohol (gasoline plus ethanol). After that, more ethanol was also produced to be used as E100 fuel and for export, besides being used in gasoline blending. Therefore, there was a tendency for this indicator 
(FL) to fall for ethanol and for this to stop being a key sector of the economy as an input supplier.

The backward linkage (BL) relates to sectors in the matrix that purchase products from other sectors of the national economy. In this context, the sectors are ranked in descending order as follows: sugar; ethanol; petroleum refining; sugarcane and oil extraction. Only sugar and ethanol are key input-consuming sectors in the Brazilian economy, exhibiting BL higher than one. However, it is interesting to observe that both sugar end ethanol decreased their importance as consumers in the economy. While in 1970 the BL for these sectors was 1.3, in 2006 the BL was 0.9 and 1.1 respectively for ethanol and sugar. Other sectors analyzed were independent of interindustry supply.

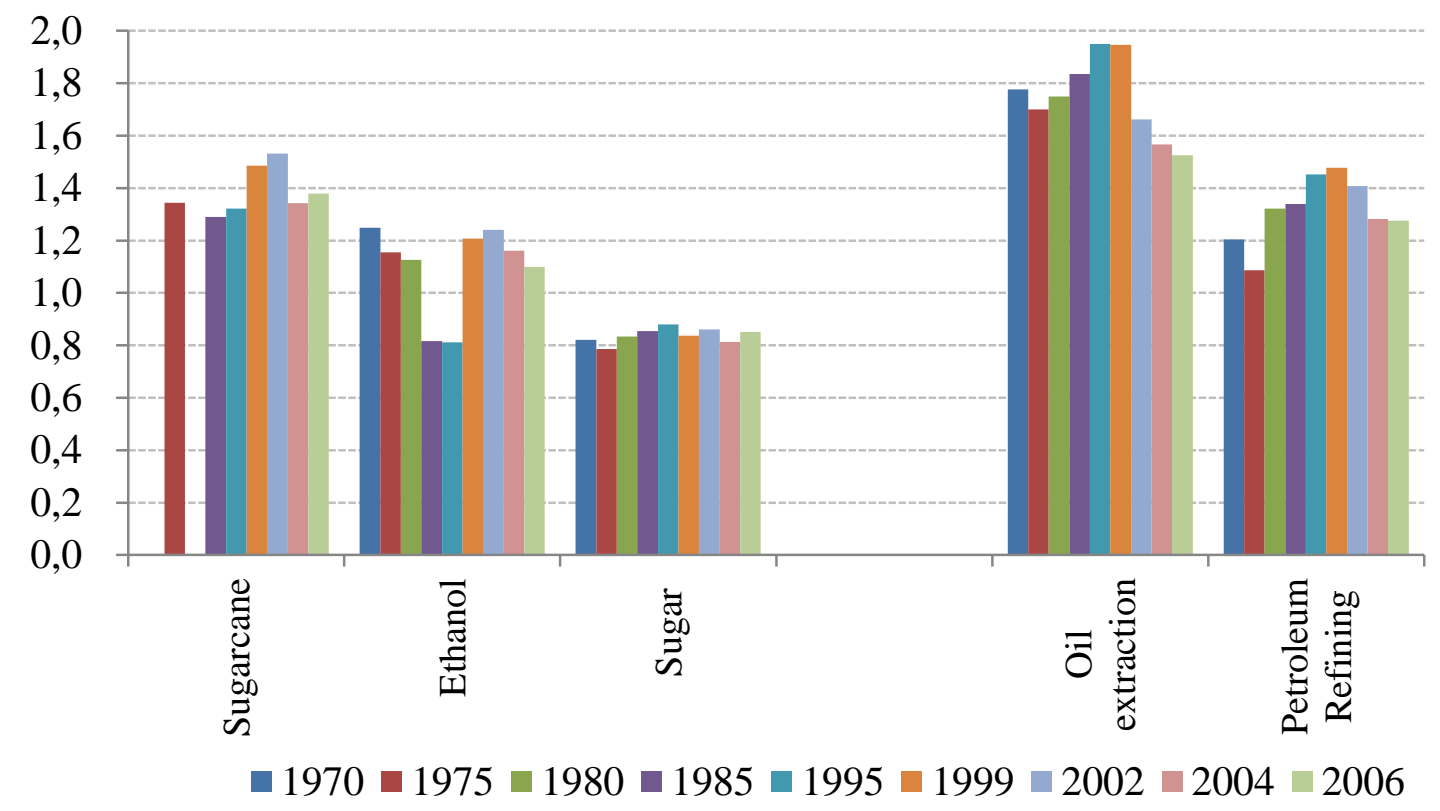

Figure 5 - Rasmussen-Hirschman forward linkages (FL) for selected sectors, 1970 to 2006.

Sources: research results. 


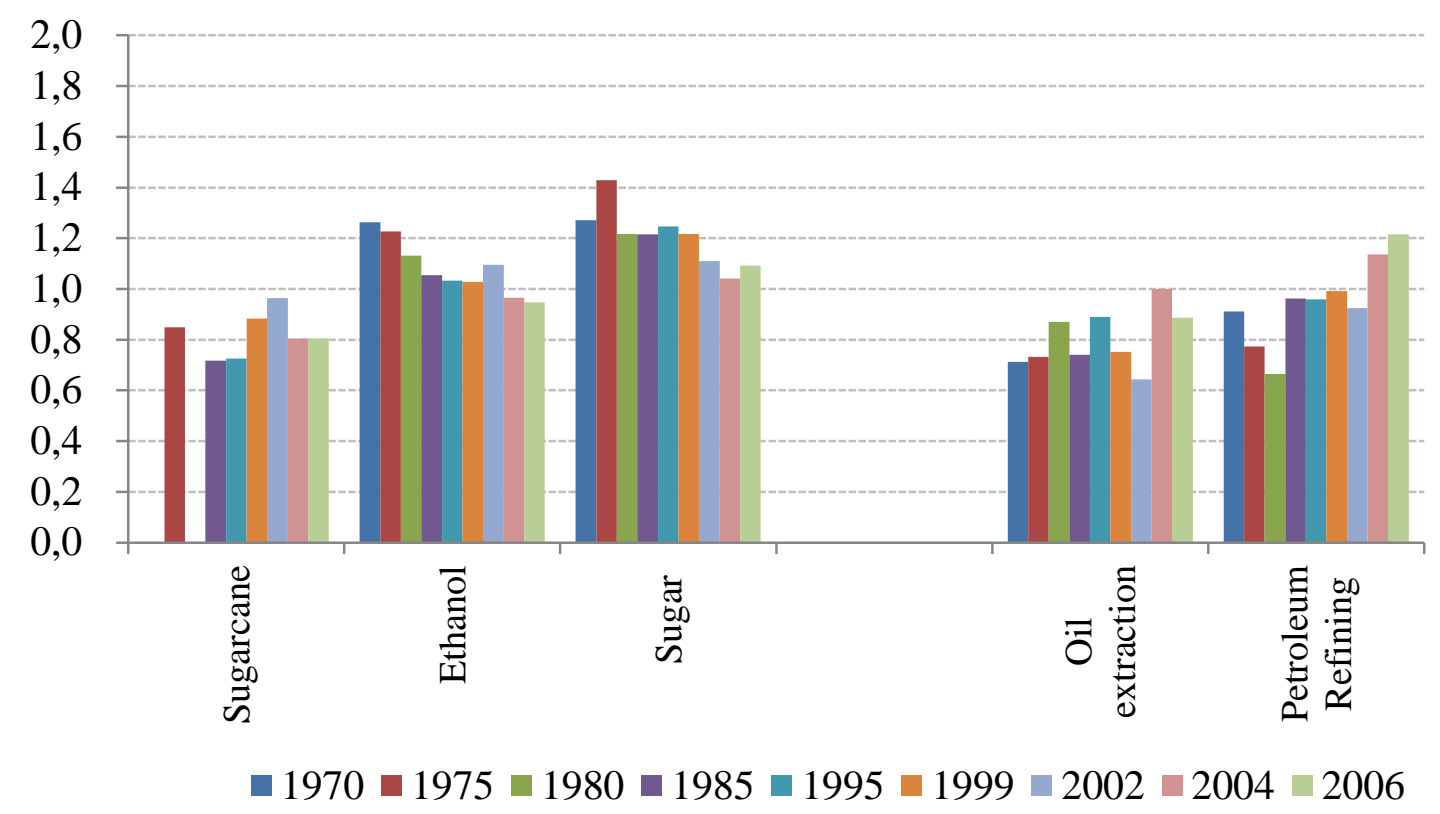

Figure 6 - Rasmussen-Hirschman backward linkages (BL) for selected sectors, 1970 to 2006.

Sources: research results.

According to the classification of backward and forward linkage shown in Table 1 and considering the average values of FL and BL calculated for the five sectors, only the sugar sector can be classified as dependent on interindustry supply, while sugarcane, oil extraction and petroleum refining are classified as dependent on interindustry demand. Ethanol was dependent on both sides (interindustry supply and demand) and is classified as generally dependent. However, as described previously, it shows a trend towards being classified as sugar: dependent on interindustry supply.

Thus, if the government wants to invest in a sector to incentivize the whole-economy purchasing of inputs for this investment, the cane agro-industry is preferable. Conversely, if the government wants to invest in a sector and supply more inputs to the whole-economy, the petroleum industry is the better choice. Besides, the complete mechanization of sugarcane cutting in the next years should increase the BL in this sector.

\subsubsection{The Pure Linkages}

An alternative index that takes into account the relative size of the sectors in the economy is the pure linkage. The results for these indices to the cane agro-industry sectors (or sugarcane group) and petroleum sectors (or oil group) are presented in Figures 7 and 8 respectively, for pure forward linkage (PFL) and pure backward linkage (PBL). As illustrated 
in these figures, this methodology leads to a greater difference between the sugarcane group and oil group results. Basically, this disparity arises from the higher production value of the oil sector in the country, increasing its importance as supplier or purchaser of inputs in the economy.

The PFL index showed a much greater distinction between the sugarcane and oil groups (Figure 7). Within the sugarcane agro-industry, the profiles were similar, even over the years. The PFL value in this group ranged between 0.1 and 0.4 . In the oil group, petroleum refining had a far higher PFL than oil extraction, the former PFL ranging between 1.0 (1970) and 3.1 (1999), and the latter PFL between 0.1 (1975) and 1.2 (2006). Despite the PFL value for oil extraction being higher than those in the sugarcane group, neither oil extraction nor sugarcane group were key sectors in the Brazilian economy.

The PBL values were less than one for all sectors and in all years analyzed. This means that these sectors were not important as purchasers on average in the Brazilian economy. One interesting consideration is about sugar and ethanol. We can see in Figure 8 that these products behaved differently. When the PBL for sugar decreased to a minimum in 1980-85, this index for ethanol increased greatly and, when the PBL for ethanol decreased in 1999-02, the index increased for sugar. These moments correspond to changes in the use of the sugarcane, at a higher rate for sugar or ethanol, as shown in Figure 9.

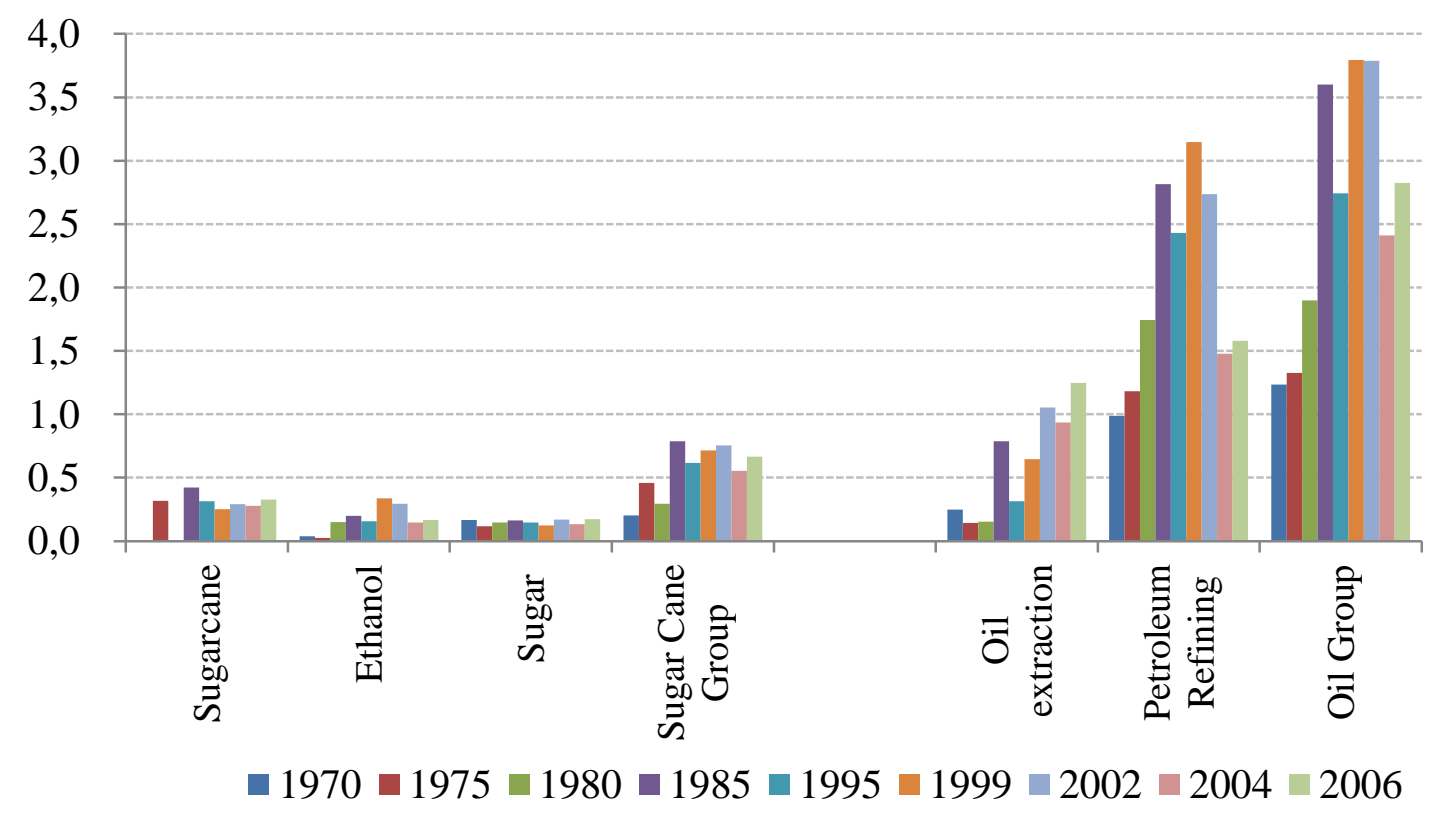

Figure 7 - Pure forward linkages (PFL) for selected sectors, 1970 to 2006.

Sources: research results. 


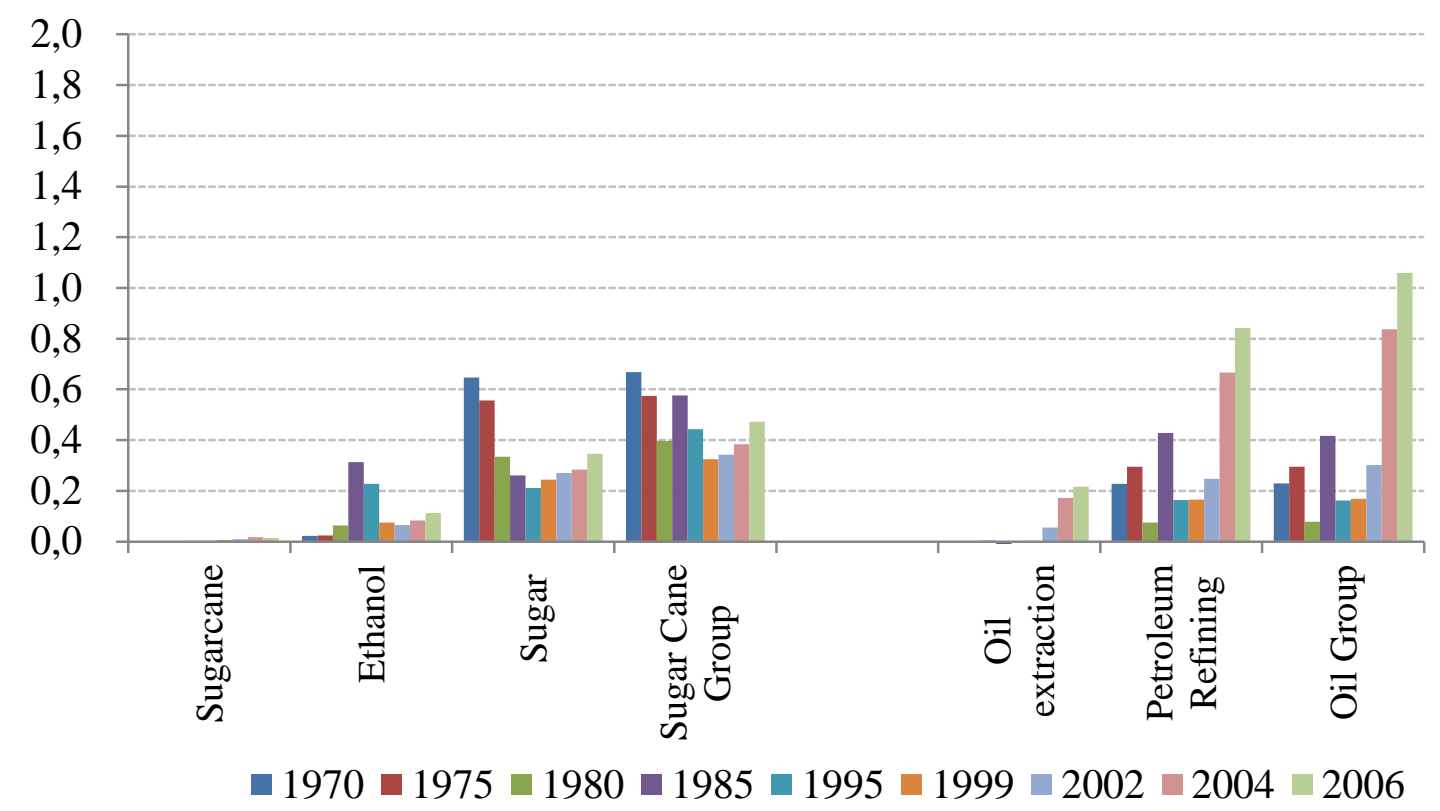

Figure 8 - Pure backward linkages (PBL) for selected sectors, 1970 to 2006.

Sources: research results.

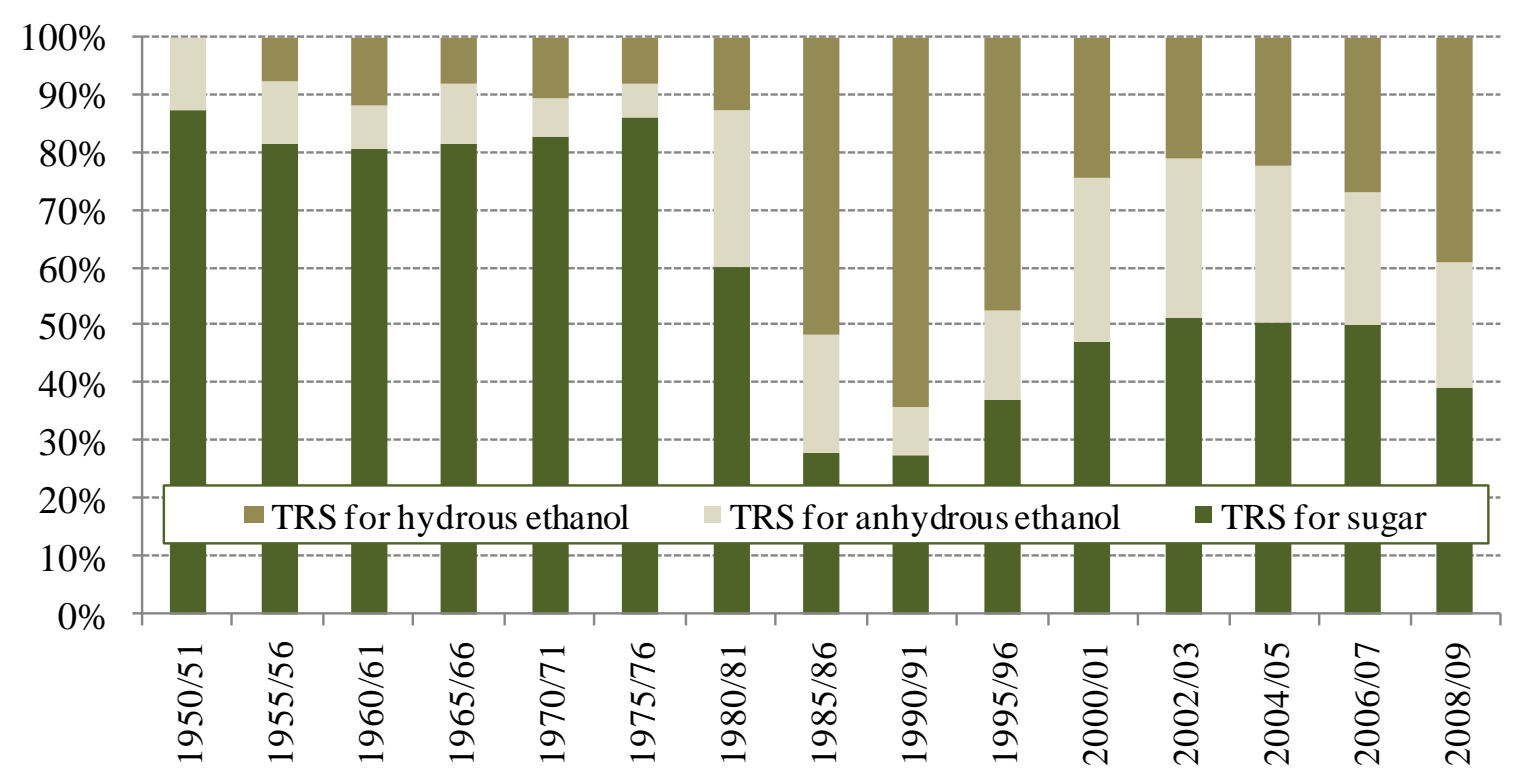

Figure 9 - Sugarcane used for sugar, anhydrous ethanol and hydrous ethanol (E100) in Brazil. Period: from 1950/51 to 2008/09.

Note: TRS is total recoverable sugar.

Sources: Brazil (2009).

However, it is interesting to realize that the PBL for the oil group increased in the importance in economy only in the last years (2004 and 2006). Before that, these sectors had less importance as input purchasers in the Brazilian economy than the sugarcane group 
(Figure 8). Nevertheless, its contribution is small compared to the value of production of these sectors and the sugarcane group maintained its importance in the economy.

\section{Final Comments}

Energy sources for the light vehicles in Brazil changed in the last decades, ethanol emerging as a complementary alternative solution. While total ethanol production was 600 thousand $\mathrm{m}^{3}$ in the $1970 \mathrm{~s}$, in 2000 it was 10.5 million $\mathrm{m}^{3}$ and in 2008 it was 27.5 million $\mathrm{m}^{3}$. Thus, this study contributes to our understanding of these changes, by assessing the importance of this fuel in the Brazilian economy, measuring its impacts, comparing it with its substitutes in production (sugar) and in consumption (petroleum derivatives) and identifying if the behavior of these sectors changes in time.

These results could help the Brazilian government to establish goals for energy investments. The government could take into consideration multiplier effects, employment generated and incentives to the purchase or supply of inputs.

We conclude from this study that the cane agro-industry exhibited considerable changes over the last three decades. Comparing the cane agro-industry and the oil industry, this study shows that: a positive shock in the final demand of the ethanol and sugar sectors would promote greater increases in Brazilian production than the other sectors analyzed; the income effect was proportionally larger for sugarcane sector than the others; production in cane agroindustry generates much more employment than in the oil industry; the backward indices are higher for the cane agro-industry than for oil and the forward index is greater for petroleum refining than sugarcane only if we consider the size of production (pure linkages).

\section{References}

BNDES (2008) Banco Nacional de Desenvolvimento Econômico e Social, CGEE - Centro de Gestão e Estudos Estratégicos. Sugarcane-Based Bioethanol. Energy for Sustainable Development. $1^{\text {st }}$ Edition, Rio de Janeiro - November 2008.

BP (2009). Statistical Review of World Energy June 2009. Available at: www.bp.com/statisticalreview. Accessed: 30 de maio de 2011.

Brazil (2009). Brazilian Ministry of Agriculture, Livestock and Food Supply. Agrienergy Statiscal Yearbook 2009. Available at: www.agricultura.gov.br/desenvolvimentosustentavel/agroenergia/publicacoes. Accessed: 01 de junho de 2011.

Brazilian Automotive Industry Association - ANFAVEA (2010). Brazilian Automotive Industry Yearbook, 2010. Available at: www.anfavea.com.br/anuario.html. Accessed: 30 de maio de 2011. 
CGEE (2009) Centro de Gestão e Estudos Estratégicos. Bioetanol combustível: uma oportunidade para o Brasil. 2009. Available at: www.cgee.org.br/publicacoes/bioetanol2_2009.php. Accessed: 01 de junho de 2011.

EIA (2010). US Energy Information Administration. Short Term Energy Outlook - April 2010.

EMBRAPA (2009). Brazilian Sugarcane Agroecological Zoning. Rio de Janeiro, RJ. Available at: www.cnps.embrapa.br/zoneamento_cana_de_acucar/. Accessed: 31 de maio de 2011.

EPE (2010) Energy Research Company. Brazilian Energy Balance 2010, year 2009. Rio de Janeiro: EPE, 2010. Available at: https://ben.epe.gov.br/BENRelatorioFinal2010.aspx. Accessed: 01 de junho de 2011.

Goldemberg, J., Coelho, S. T., Nastari, P. M., Lucon, O. (2004) 'Ethanol learning curve - the Brazilian experience'. Biomass and Bioenergy 26 (2004) $301-304$.

Goldemberg, J., F.E.B. Nigro, and S.T. Coelho (2008) Bioenergia no Estado de São Paulo: situação atual, perspectivas, barreiras e propostas, São Paulo: Imprensa Oficial do Estado de São Paulo. 152p.

Guilhoto, J.J.M., U.A. Sesso Filho (2005) 'Estimação da matriz insumo-produto a partir de dados preliminares das Contas Nacionais'. Economia Aplicada, 9 (1):, abr-jun 2005.

Guilhoto, J.J.M., U.A. Sesso Filho (2010). “Estimação da Matriz Insumo-Produto Utilizando Dados Preliminares das Contas Nacionais: Aplicação e Análise de Indicadores Econômicos para o Brasil em 2005". Economia \& Tecnologia. UFPR/TECPAR. Ano 6, Vol 23, Out./Dez. ISSN 1809-080X.

Guilhoto, J.J.M., M. Sonis, G.J.D. Hewings and E.B. Martins, (1994) "Índices de ligações e sectores chave na economia Brasileira: 1959-1980" Pesquisa Planejamento Econômico 24: $287-314$

Guilhoto, J.J.M.; M. Sonis; J.D. Hewings (2005). "Linkages and Multipliers in a Multiregional Framework: Integration of Alternative Approaches". Australasian Journal of Regional Studies, Vol. 11, No. 1. pp. 75-89.

Hewings, G.J.D. (1982) "The Empirical Identification of Key Sectors in an Economy: A Regional Perspective" The Developing Economies, 20:173-195

Hirschaman, A.O. (1958) The Strategy of Economic Development, Yale University Press, New Haven.

IBGE (2009) Brazilian Bureau of Geography and Statistics. Produção Agrícola Municipal 2009. Available at: www.ibge.gov.br/home/estatistica/economia/pam/2009/PAM2009_Publicacao_completa.p df. Accessed: 01 de junho de 2011.

IBGE (2010) Available at: http://www.ibge.gov.br/home/default.php. Download. Estatísticas. Contas Nacionais. Sistemas de Contas Nacionais. 2008. Accessed: 15 de fevereiro de 2010.

LMC (2010) “Ethanol Quarterly - 1st Quarter, 2010.” Oxford: LMC International

Macedo, I.C., Seabra, J.E.A., Silva, J.E.A.R. (2008). 'Green House Gases Emissions in the Production and Use of Ethanol from Sugarcane in Brazil: The 2005/2006 Averages and a Prediction for 2020'. Biomass and Bioenergy, 32: pp.582-595. 
McGilvray, J. (1977). "Linkages, Key Sectors and Development Strategy". In: Leontief, W. (ed.). Structure, System and Economic Policy. Cambridge University Press, p.49-56.

Miller, R.E. and P.D. Blair (2009) Input-Output Analysis: foundations and extensions, ed. Cambridge: Cambridge University Press.

Moraes, M.A.F.D. (2007) 'Indicadores do mercado de trabalho do sistema agroindustrial da cana-de-açúcar do Brasil no período 1992-2005', Estudos Econômicos, São Paulo, v.37, n.4, p.875-902.

Puerto Rico, J.A. (2007) 'Programa de Biocombustíveis no Brasil e na Colômbia: uma análise da implantação, resultados e perspectivas', Master's thesis. Universidade de São Paulo.

Rasmussen, P.N. (1956) Studies in Intersectoral Relations, North-Holland, Amsterdam. 